\title{
Absence: An Indo-Analytic Inquiry
}

\section{By}

\section{Anand Jayprakash Vaidya \& Purushottama Bilimoria with Jayshankar L. Shaw}

\begin{abstract}
:
Two of the most important contributions that Bimal Krishna Matilal made to comparative philosophy derive from his (1968) doctoral dissertation The Navya-Nyāya Doctrine of Negation: The Semantics and Ontology of Negative Statements in Navya-Nyāya Philosophy and his (1986) classic: Perception: An Essay on Classical Indian Theories of Knowing. In this work we aim to carry forward the work of Bimal K. Matilal by showing how ideas in classical Indian philosophy concerning absence and perception are relevant to recent debates in analytic philosophy. In particular we focus on the recent debate in the philosophy of perception centering on the perception of absence.

In her Seeing Absence, Anya Farennikova (2013), argues for the thesis that we literally see absences. Her thesis is quite novel within the contexts of the traditions that she engages: analytical philosophy of perception, phenomenology, and cognitive neuroscience. In those traditions there is hardly any exploration of the epistemology of absence. By contrast, this is not the case in classical Indian philosophy where the debate over the ontological and epistemological status of absence (abhāva) is longstanding and quite engaging. In what follows we engage Farennikova's arguments, along with those of John-Rémy Martin and Jérome Dokic in their (2013) response paper to her work, through the use of classical Indian philosophers and their $20^{\text {th }}$ century proponents. Using the work of Bimal K. Matilal (1968, 1986), Purushottama Bilimoria (2015), Jaysankar L. Shaw (2016), show that there are several engaging ideas that can be taken from Indian philosophy into the terrain explored by Farennikova, and Martin \& Dokic. Our aim is to provide an updated comparative engagement on absence and its perception for the purposes of enhancing future discussions within analytic philosophy. However, we do not aim to merely show this by focusing on the history of classical Indian philosophy or on $20^{\text {th }}$ century commentary on classical Indian philosophy. Instead, we hope to show the living tradition of Indian philosophy that Matilal embodied carries forward in his students and colleagues as they revive and extend Indian philosophy.
\end{abstract}

\section{The Current Debate on Seeing Absence in Analytic Epistemology and Cognitive Science}

There are many situations in the world that can be categorized by appeal to the generic idea of having an experience of absence. The most obvious and relevant one for this paper is the obvious way in which students of Bimal Matilal might experience his absence when visiting a lecture hall at Oxford, a café in Calcutta, by seeing his notes or a favorite book of his.

While there is a long discussion in the history of western philosophy on the ontology of absence, there is little exploration of the epistemology of absence. However, 
that situation has recently been rectified by the brilliant work of Anya Farennikova (2013) and the engaging exchange with it by Jean-Rémy Martin \& Jérôme Dokic (2013). In the next two sections we offer an account of their positions and arguments. As a way into their work we begin with a presentation of the phenomenon under consideration and two of the main views that are being explored in the analytic terrain. The opening case study of Farennikova's work is the case of the missing laptop, from which she moves into a presentation of the paradox of absences perception

The Case of the Missing Laptop:

You've been working on your laptop in the cafe for a few hours and have decided to take a break. You step outside, leaving your laptop temporarily unattended on the table. After a few minutes, you walk back inside. Your eyes fall upon the table. The laptop is gone!

This experience has striking phenomenology. You do not infer that the laptop is missing through reasoning; you have an immediate impression of its absence.

The Paradox of Absence Perception:

However, absence perception presents a paradox. On prevailing theories of perception, we see only present objects and scenes (Marr 1982; Gibson 1966; Dretske 1969). So we cannot literally see something that is not present. This suggests that we never actually perceive absences; instead, we come to believe that something is absent on the basis of what we perceive. But this cognitive explanation does not do justice to the phenomenology. Experiences of absence possess immediate perceptual qualities. One may further argue that the ability to rapidly detect absences confers adaptive advantage and must be as fundamental to humans as is seeing positive things. (Farennikova 2013: 430)

Both Farennikova, and her opponents, Jean-Rémy Martin \& Jérôme Dokic, accept the idea that there are at least two competing explanations of the experience of absence: (i) the perceptual view and (ii) the cognitive view. The Perceptual View states that absence experiences instantiate a perceptual phenomenology just as experiences of present objects. Within the framework of the representational theory of perceptual experiences this means that perception represents absences as it represents present objects. ${ }^{1}$ The Cognitive View states that the perceptual phenomenology of absence experiences collapses with the phenomenal character of sensible qualities instantiated by the background: the perceptual experience of the wall is the same whether an absence is noticed or not. Therefore, one might argue that we don't literally perceive absences; instead, we come to believe or judge that something is absent on the basis of what we do perceive. $^{2}$

${ }^{1}$ See Martin \& Dokic (2013: 1-2) for this account of the perceptual view.

${ }^{2}$ See Martin \& Dokic (2013: 1-2) for this account of the cognitive view. 
Farennikova defends the perceptual view and argues against the cognitive view. Martin \& Dokic argue against to the perceptual view, and defend a distinct view called the metacognitive view, which we will introduce in our presentation of their work. For those familiar with classical Indian philosophy as well as work done on it in the $20^{\text {th }}$ century it should be abundantly clear what is underway in this debate is similar and also dissimilar to the classical debate over abhāva in classical Indian philosophy. Matilal describes the situation in Indian philosophy as follows.

Traditionally the problem of absence (abhāva) comprises the following specific questions: (a) Is abhāva to be accepted as a means to true cognition? (b) Is absence a separate category? (c) How is an absence of something cognized? A related but no less interesting question is: (d) How many kinds of absence are there? These points have been discussed and criticized by various philosophers of different schools at different times in different contexts. The literature on this subject is rich and varied.

(Matilal 1968: 99)

We will return to some of his insights concerning the Nyāya and Navya-Nyāya tradition in 4.

\subsection{The Perceptual View of the Epistemology of Absence}

Moving off of recent debates in the philosophy of perception, cognitive science, and vision science Farennikova propose a theory of how we see absences that by our lights is brilliant and well defended. Her theory is called the 'mismatch model of seeing absence', MM, hereafter. The method she uses for arguing for her view takes three important steps. First, it isolates a set of cases in which the phenomenology of absence can be captured, examined, and defended so that there is a datum that has to be explained. Second, it offers a set of theories that can be used to explain the data. Third, it argues against some the theories, and then goes on to show how a single theory, MM, offers the best explanation.

Our presentation will of these steps. Consider her isolation of the relevant set of cases.

Let's think of the situations when we usually perceive absences. You are about to make coffee and discover that the coffee jar is empty; or you expect an important document in the mail but there is nothing in your mailbox; or you make a trip to a bakery only to see that your favorite desert is missing from the display. These situations, in essence, are failed visual searches: you begin to look for an object, expecting it to be at a certain place, and see its absence when your expectation is disconfirmed. Given that seeing absence often occurs due to a violation of expectation, analysis of this process should give us important clues about the mechanisms of perception of absence. (Farennikova 2013: 440) 
For Farennikova failed searches seem to be the paradigm case. As a consequence her argument for MM can be given by focusing on those cases.

1. There are experiences of absence.

2. Experience of absence in failed searches can be explained through the mechanism of mismatch that subserves violation of expectation in failed searches.

3. MM can generalize properly from the experience of absence in failed search cases to other experiences of absence that do not involve a failed search.

$\therefore$

4. $\mathrm{MM}$ is the best explanation of the experience of absence.

The core of the argument is that movement from the case where MM is a solid explanation to the cases where it must also work in order to be the best explanation. Farennikova goes into an articulation, explanation, and defense of both the failed search case, as well as other kinds of cases that she takes to exhaust the space of the phenomenology of absence. ${ }^{3}$

Absence Experience by Failed Search: Suppose you are looking for your keys in your room, because you are certain that you brought them into your room. After looking around the room, in draws on the dresser, you have the visual experience of your keys being absent. In this case you had an expectation that your keys were in your room, and that expectation was violated. The search begins with the generation of a template that is projected for the purposes of comparison. The keys can only be found if they match a template. An experience of absence of your keys will involve a mismatch between their template and the places viewed during search.

Absence Experience by Pattern Priming: Suppose you are at a museum and you are walking down a row of photographs, and you have the experience of an absence by noticing that photograph is missing in the series of photographs. In this case you did not intentionally search for the photograph, but nevertheless you have an absence experience. The explanation can be given via the idea of priming. The prior pattern of photographs prime's you to have an expectation of what will be found in the series. The disconfirmation of your prediction will generate an experience of absence.

Absence Experience by Destruction or Disappearance: The burst of a balloon, a coin magically vanishing from a hand, or a lover disappearing into the crowd is an experience of absence that occurs by destruction or disappearance of the relevant item. In these scenarios, we experience absences of objects when we lose perceptual contact with those objects. If experiences of this sort are caused by loss of contact, it does not follow that we will not also need to account for them through mismatch. Without mismatch our experience will be one of a succession of events. Consider watching the sun set behind the ocean and intently tracking its trajectory. Now consider the time when the last bit of the sun disappears. Without the mismatch, your experience will be that of attending to the sun, followed by attending to the ocean, once the sun disappears both positive percepts. Mismatching is necessary to transform this succession of positive experiences into an experience of absence.

\footnotetext{
${ }^{3}$ See Farennikova (2013: 441-443)
} 
She also carefully clarifies her use of mismatch and templates through three important qualifications: ${ }^{4}$

(a) Level Propriety: Mismatches must be at the right level for the explanation to work.

(b) Pluralism about Templates: Object-level mismatches will vary in the perceptual profiles because the process or tasks that produce them will employ templates with different characteristics. Thus, 'template' does not refer to a single type of representation but to a family of representations. For example, templates might not be visual images like pictures, but instead maybe representations produced at the subpersonal level and projected involuntarily. They will lack the vivacity of conscious imagery.

(c) Absence Experience Requires Interpretation of Mismatch: Processes that produce object level mismatches will affect the interpretation of these mismatches by engaging different sets of expectations. Mismatches must be interpreted to produce an experience of absence otherwise the mismatch model would produce experience of absences every time there is a mismatch.

In light of these cases and the qualifications Farennikova's mismatch model is::

MM: Visual experience of $O$ 's absence consists in an object-level mismatch between $O$ 's template generated by visual working memory and a percept of the observed stimulus. ${ }^{5}$

With MM in place she offers an account of the original case she began with.

Consider the empty cafe' table from the laptop example. On its own, the table cannot tell us that something is missing or what is missing. While a cake may leave signs of its absence (crumbs and guilt on your partner's face), absence of a laptop from the table can be completely traceless. So, how do we come to represent that the laptop is absent? It is not enough to represent the table, even with some zooming effects. This would be positive seeing: viewing of the table as such. Nor is it enough to visualize the missing computer in your mind. This would be a mere remembrance of the laptop, or imagining what it looks (or would look) like under certain conditions. Representing absence, I argue, involves relating the percept of the table to the image of the laptop in form of a mismatch.

(Farennikova 2013: 444).

While she does offer several arguments against other views, we will forgo discussion of them in order to focus on an alternative view in the literature that challenges her perceptual view.

\footnotetext{
${ }^{4}$ See Farennikova (2103: 442-444).

${ }^{5}$ See Farennikova (2013: 444).
} 


\subsection{The Meta-Cognitive View of the Perception of Absence}

M\&D have a two-sided approach to the epistemology of absence. They first offer an argument against the Perceptual View that Farennikova defends. Second, they develop a meta-cognitive account. The main argument against the Perceptual View departs from consideration of the case of 15 Boxes.

15 Boxes Case: You are presented with two series of fifteen successive boxes. In the first series, the first ten boxes contain red marbles but the eleventh box surprisingly reveals a green marble while you implicitly expected a red marble. The second series is like the first, except that the eleventh box surprisingly reveals nothing while you expected a red marble.

\section{Argument}

1. There is a unified type of phenomenology co-present in the two series of the 15 Boxes Case. In the first series we encounter an unexpected mere change. In the second series we experience an absence. The unified phenomenology is considered to an instance of the affective state of having a feeling of surprise, FoS.

2. FoS constitutes the affective state of incongruity and surprise.

3. FoS is compatible with a variety of perceptual contents including, but not restricted to, absence situations.

4. FoS underdetermines the Perceptual View in all cases.

$\therefore$

5. The Perceptual View offers the wrong account of the phenomenology of absence.

M\&D describe the situation with respect to Farennikova as follows:

[T] he experience of incongruity targeted by Farennikova is not specific to absences situations but is constituted by a FoS which can be caused by various types of mismatch. This clam is prima facie compatible with both the Perceptual View and the Cognitive View. ... [However] FoS is reducible neither to perception or belief, but should be conceived as a type of metacognitive feeling. Eventually, both the Perceptual View and the Cognitive View will be rejected in favor of the Metacognitive View. Martin \& Dokic 2013: 4)

M\&D offer a third option from those considered by Farennikova. Their option interestingly engages affective states and metacognition, cognition of cognition, as opposed to cognition. They go on to develop a metacognitive by pulling from a number of researchers such as Koriat $((2000,2007)$. We will present their view by way of $n$ argument. $^{6}$

\footnotetext{
${ }^{6}$ See Martin \& Dokic (2013: 4-6). This is our reconstruction of their argument.
} 
1. Metacognitive judgment derives from either of two sources. Theory-based judgments are conclusions of explicit inferences from encyclopedic background knowledge or knowledge of one's own skill. Experience-based judgments result from an affective experience, particularly what is referred to as a metacognitive feeling.

2. Absence experiences are qualitatively identical to experiences of unexpected changes. Both involve the feeling of surprise, FoS.

3. The experience of incongruity common between absence experiences and unexpected changes that is at play in the perception of absence is affective rather than perceptual. The mismatch in the experience of absence does not give rise to a perceptual experience of absences, but to a metaperceptual feeling of surprise or unxpectedness. FoS comes from the monitored mismatch between the subject's expectations and the actual state of the world.

3. The metacognitive view is not affected by objections to the cognitive view. Since, the metacognitive feelings are process-based, rather than content-based. The metacognitive view is not a variant of the cognitive view, since metacognitive feelings are not beliefs, and some times they are independent of beliefs.

4. The metacognitive view does justice to the phenomenology of absence experience.

5. The perceptual view gives the wrong prediction / explanation in the 15 Boxes case.

$\therefore$

6. The metacognitive view is at least as good as the perceptual view when it comes to explaining absence experiences.

As Martin \& Dokic say, "we don't see absences, but we may feel surprised when there is an absences of seeing. (2013: 8)" We will refer to the metacognitive model as, MCM.

\section{An Analytical Path To Classical Indian Philosophy}

In this section we want to transition from the analytical debate over the perception of absence to the classical Indian debate over absence. Rather than doing that by jumping directly into classical Indian philosophy, we want to make several important analytical points about Farennikova's arguments and model as well as M\&D's arguments and model of how we see absences.

First, both Farennikova and M\&D take the phenomenology of absence seriously and use that as a data point into their own models and arguments. As a general point we would like to note that one move in the debate, partially used by M\&D against Farennikova, is to challenge the claim that all the phenomenological data is in. While it is quite clear that Farennikova tries to capture a variety of cases, and M\&D offer some challenging cases that put pressure on the very phenomenology she is trying to capture, we wonder whether this is all the data. When we turn to the debate in classical Indian philosophy we will attempt to show that there is more phenomenological data out there, and it needs to be covered. 
Second, Farennikova argues that "we can literally see absences; in addition to representing objects, vision represents absences of objects (2013: 430)" This statement of her thesis leads us to the question: is literally seeing an object the same as representing an object? The analytical point we wish to make departs from taking into consideration the difference between factive and non-factive uses of ' $x$ sees $y$ '. On the factive reading of ' $x$ sees $y$ ' it follows that there is some $y$ such that $x$ sees it. On the non-factive reading of ' $x$ sees $y$ ' it does not follow that there is some $y$ such that $x$ sees it. For example, on the factive reading of sees, if $x$ sees a tree, then there is a tree that $x$ sees. By contrast, on the non-factive reading of sees, if $x$ sees a tree, then it need not be the case that there is a tree that $x$ sees. The factive reading of sees renders it veridical, while the non-factive reading renders it consistent with non-veridical experience. Simply put, hallucinating a tree is different than seeing a tree, however in both cases one can legitimately say 'I see a tree'. And under some uses of 'representing' a tree is represented both cases.

Moving off of this point it is important to note that on the factive reading we are invited into a different set of questions than on the non-factive reading. On the factive reading, if $x$ sees the absence of $y$, then there must an absence of $y$ that $x$ sees. That means that the epistemology of absence cannot be divorced from the ontology of absence. To say that we literally see absences means that there are absences to be seen. We note that nowhere in Farennikova's or M\&D's work is there any discussion of the ontology of absence. As we will soon see: everywhere in classical Indian philosophy the ontology of absence is at play in discussions of the epistemology of absence. Correspondingly, if the thesis is that "vision represents absences of objects" than we wonder how controversial this thesis is, such that we can talk about "literally seeing absence". Granted Farennikova is entitled to discuss the issue from within the purview of a representational theory of seeing where the aim is to show that we represent absences in the perceptual system, but this is not a strong license for the perceptual view. When we turn to Indian philosophy we will see a version of the perceptual view that has a stronger claim to the claim that "we literally see absences'

Third, if we are to have a comprehensive theory of the how we see absences than we ought to have an attendant theory of how we fail to see absences. That is, if there is veridical perception of absence, via veridical representation, then there must be nonveridical perception of absence, via an account of error. If I can perceive absence, I can misperceive absence. And if I can't misperceive absence, then the perception of absence is very different from the perception of presence, and thus it is worth pointing this out. However, neither Farennikova nor M\&D discuss this issue. Although both of their arguments and theories are brilliant, we think that classical Indian philosophers that have explored the issue of perception of absence have also explored error with respect to the perception of absence.

Fourth, it is quite clear that Farennikova's theory appeals to images and / or items that play a role in how vision represents absence, while M\&D's account is perhaps neutral on that issue. We take no quarrel with the idea that vision utilizes such items. However, we wonder if an account of the epistemology of absence needs to do this. For our purposes we see that some Indian philosophies engage the perception of absence by claiming two things: (i) we literally see absences, and (ii) we don't see absence on the basis of an image, but rather on the basis of causal conditions, both positive and negative, 
obtaining between the perceiver and the perceived object, in the case of absence, the absentee.

Fifth, Farennikova's argument proceeds by distinguishing different kinds of cases where we have the phenomenology of absence. M\&D appear to challenger her taxonomy by pointing to the non-distinguishability between cases of absence perception and cases of unexpected changes, which they claim reveals the true phenomenon at play: the feeling of surprise, which is meta-cognitive. Farennikova's separation of cases depends on a principle of division. The principle of division appears to depart from the paradigm case, failed searches. And then it moves on to pattern cases and disappearance cases. However, one might ask two questions: (i) given her principle of separation, are there any other kinds of cases that have not be identified and accounted for? and (ii) is there another principle of division that leads to a non-overlapping set of distinct cases? We will pick up this point both in our presentation the Nyāya and in our presentation of the BhāttaMīmāmsā schools of Indian philosophy. Both of these schools accept the idea that absences can be differentiated on the basis of time, (a) not-yet cases, (b) no-more cases, and (c) never-never cases. That is, they present absence experiences in a time-dynamic model as the basic phenomenon. The fact that they cut up the problem space differently leads to a potential explanatory problem for Farennikova and M\&D's theories. Either they must show that all cases that are not of the kind that these schools identify can be covered by an extension of their theory or the cases that are captured through the different principle of separation are reducible to their own account of the distinct kinds of cases. The argumentative point is simple: if absences are arguably not captured through the principle of division each accepts and their theories cannot be extended to cover the relevant kind of case, then the exploration of classical Indian discussions of the philosophy of absence leads to an interesting insight for theory construction in the area.

These five points are guides to the opening of our discussion of absence in Indian philosophy. We would like to close this section by considering a general issue in the philosophy of perception that moves off of the branch that Farennikova is exploring. Recall that her engagement with the perception of absence departs largely from having a representationalist view of perception in the background. But some people, such as John McDowell (2009), have denied representationalism about perception and gone in for disjunctivism.

Disjunctivism About Perceptual Experience, DAPE:

But suppose we say - not at all unnaturally - that an appearance that suchand-such is the case can be either a mere appearance or the fact that suchand-such is the case making itself perceptually manifest to someone. As before, the object of experience in the deceptive case is a mere appearance. But we are not to accept that in the non-deceptive cases too the object of experience is a mere appearance, and hence something that falls short of the fact itself. (McDowell 2009: 80)

This leads to an interesting question: what happens when you combine the perception of absence with disjunctivism? 
Realism About Absence Experience, RAAE:

We literally do perceive absences.

No one in the analytic literature has considered these two claims together. The disjunctivism literature has not engaged the question of the perception of absence, and the absence literature has not engaged disjunctivism. Putting these two theses together leads to a very interesting question in the philosophy of perception: How can disjunctivism about perception be true, given that we literally do perceive absences? We highlight this question for the purposes of bringing out a new and interesting cross-cultural question in the philosophy of perception. Interestingly, in the classical Indian tradition, at least one school of thought, the Nyāya, has argued for realism about absence experience while also engaging a thesis that has been argued to be in the range of disjunctivism about perceptual experience. We discuss the importance of this view in our discussion of Nyāya.

\section{A Partial Geography of the Absence Debate in Classical and Indian Philosophy}

There are many participants to the debate on the ontological and epistemological status of absence in classical Indian philosophy. Perhaps one of the best recent surveys of the classical Indian terrain is Nirmalya Guha's (2013) in which he presents an exemplary survey of three schools of Indian philosophy, two branches of Mīmāṃsā (Bhātța and Prābhākaran) and the Nyāya with respect to both ontological and epistemological questions concerning absence. However, his excellent survey does not engage material found in the Jain and Buddhist traditions of philosophy. For our purposes, and for contrast with the analytical exploration, we will look only at two schools, the Nyāya and the Bhăța-Mīmāmsā. The debate between these two schools is singled out because these schools share certain assumptions. The key assumptions are. Realism about absence cognition, which holds that the cognition of absence is a real phenomenon, which is not reducible to another phenomenon. Knowledge of absence, which holds that we can know absences. For example, we can know that there is an absence of a pot on the ground. Realism about the ontology of absences, which holds that there are absences, such as the absence of a pot at a location. At least one of these assumptions, realism about absences, is not shard by either Buddhism or the Prābhākaran-Mīmāmsāa. What the disagree over is what is he best explanation of how we come to have cognitions of absence and knowledge of absence on the basis of realism about the ontology of absence.

Thus, as an initial note, the Indian tradition begins with the cognition of absence as opposed the phenomenology of absence. There is an open question as to what exactly is the connection between these two, and whether or not these traditions are exploring entirely orthogonal issues. We will move forward on the assumption that these two traditions can learn from each other. In particular, we noted earlier some skepticism about whether the analytical terrain correctly identified all of the phenomenological data concerning absence. We hold that the Nyāya would make the following argument, which suggests further phenomenological data needs to be investigated. When we perceive a pot, we perceive the pot being present at a location, but distinct from the location. 
Likewise, when we perceive an absence of a pot, we don't just perceive the locus of its absence. Rather, we perceive the absent item at the locus. This suggests a structural similarity between the perception of presence and absence. ${ }^{7}$ Moreover, in the analytic framework, our explanatory options are the perceptual view, the cognitive view, or the meta-cognitive view. However, by examining the debate between the Nyaya and the Bhăța-Mīmāmsā we can come to see other options and other ways of seeing some of the current options.

The Nyāya and the Bhātța-Mīmāmsāa debate is over whether knowledge of absence derives from perception (pratyakșa) or non-apprehension (anupalabadhi) - or the absence of seeing-, where non-apprehension is not the same as inference (anumäna). One of the main questions we will explore in the section on the Bhătța-Mīmāṃsā is what exactly is non-apprehension (anupalabadhi). For now, we would like to set out part of the important geography of the classical Indian debate in this area by presenting an exchange between an $11^{\text {th }}$ century Nyāya, Udayana, and a $12^{\text {th }}$ century follower of the Kumarila Bhaț̣a Mīmāṃsā School, Nārāyaṇa Bhaț̣a (1985: 219-223). ${ }^{8}$

\section{Udayana Argument 1:}

1. If cognition of absence derives from non-apprehension, then it would be indirect, since non-apprehension is indirect.

2. Cognition of absence is direct.

$\therefore$

3. It is not the case that cognition of absence derives from non-apprehension.

$\therefore$

4. Cognition of absence derives from perception, since it is not cognized indirectly (apāroksyāt-hetu).

Nārāyaṇa Bhaț̣a Response 1:

1. Absences do not have the property of being apprehended not-indirectly, since when we apprehend the ground where the locus of the absent pot is, we do not do it indirectly.

2. We apprehend the ground not-indirectly, but the absence is not apprehended notindirectly

$\therefore$

3. Cognition of absence is not a case of perception.

Udayana Argument 2:

1. In the cognition of absence the sense organs remain the same as when you perceive the locus of the absence. They do not change.

\footnotetext{
${ }^{7}$ J. L. Shaw is responsible for this point.

${ }^{8}$ J. L. Shaw translated the following arguments into English from the original Bengali-Sanskrit Mānameyodayah.
} 
2. If the sense organs remain the same, then the absence has the property of being perceived.

$\therefore$

3. The absence at the locus has the property of being perceived.

Nārāyaṇa Bhaț̣a Response 2:

1. The sense organs remain the same with respect to the locus of the absence. But the sense organs do not remain the same with respect to the absence, because they are not related to the negatum of the absence.

2. The case when you perceive the locus and the case when you perceive the absence are not the same for saying that the absence has the property of being perceived.

$\therefore$

3. The sense organs do not remain the same when one has cognition of absence.

\section{Udayana Argument 3:}

1. In the case of perceiving a pot on the ground, we see the pot and we do not cognize the sense organ by which we see the pot.

2. In the case of cognition of absence of a pot on the ground, we also do not cognize the sense organ by which we cognize the absence.

$\therefore$

3. By parity of reasoning, we cognize the absence through perception.

Nārāyaṇa Bhaț̣a Response 3:

1. In the perception of a pot it is true that the chief instrumental cause, the sense organs, are not cognized.

2. However, it is also true that the chief instrumental cause, the previous experience, is not cognized in memory.

$\therefore$

3. The property of not cognizing the chief instrumental cause is not sufficient to determine that absence is cognized through perception.

Udayana Argument 4:

1. If a cognition is produced by means of the chief instrumental causes, which are positive, along with the internal sense organ (manas), then it is a case of perception.

2. In the case of cognition of absence, the property of being produced by means of the chief instrumental causes, which are positive, and the internal sense organ (manas) is present.

$\therefore$

3. The cognition of absence is a case of perception. 
Nārāyaṇa Bhaț̣a Response 4:

1. In the case of the cognition of absence the chief instrumental cause is different from the sense organ used in perception.

2. If the chief instrumental cause in the case of cognition of absence is different from the sense organ used in perception, then cognition of absence is not a case of perception.

$\therefore$

3. The cognition of absence is not a case of perception.

This portion of the debate, and other debates like it, sheds light on how deep classical Indian philosophers go into the discussion of cognition of absence. But the exchange also reveals how Indian philosophers might look at the layout of the analytical debate, as well as the MM-model and the MCM-model. From the classical Indian perspective the questions are the main question is: How would the Nyāya or BhătțaMīmāṃsā classify either MM or MCM. For example:

- Is MM a perceptual account of the phenomenology and cognition of absence according to either the Nyāya or Bhāțta-Mīmāṃsā account of perception?

- Is MM an inferential account of the phenomenology and cognition of absence according to the Nyāya or the Bhâtța-Mīmāmensā account of inference?

- Is MM a non-apprehension account of the phenomenology and cognition of absence according to the Bhātța-Mīmāṃsā account of non-apprehension?

A variety of answers can be given to these questions. We select out a set of points, deriving from specific answers to these questions, that we think serve as interesting crosscultural points about the perception of absence.

- On either the Nyāya or Bhāța-Mīmāṃsā account of perception, MM is not a perceptual account of the phenomenology of absence.

- On either the Nyāya or Bhāțta-Mīmāṃsā account of inference, MM is not an inferential account of the phenomenology.

- Arguably both MM and MCM are non-apprehension accounts of the phenomenology and cognition of absence. They only differ on how the nonapprehension occurs.

\section{Discussion of Absence in Nyāya}

One of the best places to start an investigation into absence in classical Indian philosophy is through an examination of Bimal K. Matilal's classic The Navya-Nyāya Doctrine of Negation, in which he offers a thorough treatment of absence and negation within both Nyāya (the traditional school) and Navya-Nyāya (the new school). He offers translations of core material with commentary as well as metaphysical, logical, and epistemological analysis and comparison deriving from engagement with analytic philosophy. In this section we will bring to light some of the key insights he draws out from original sources 
of Nyāya, which are relevant to the contemporary debate. In addition, we will highlight important contributions that are made by another classical Indian philosopher of the $20^{\text {th }}$ century, Jaysankar Lal Shaw, who both studied with Matilal and has advanced the cause of the Nyāya treatment of absence and negation. We will focus on his work on negative causal conditions for perception. Finally, we will close with a discussion of the question concerning the combination of disjunctivism about perception and realism about absence perception, which we think is a new question to be explored in analytic philosophy, which already has been explored, in some sense, within the Nyāya tradition.

Matilal (1968) offers translations of some early figures of the Nyāya School: Akșapāda Gautama, the founder of Nyāya, and an important commentator, Vātsyāyana. The following exchange from the Nyāya Sütras, NS, sheds light on how this school of Indian philosophy begins engagement with the topic of absence (abhāva).

NS 2.2.7: [Opponent]: Abhāva is not a means of true cognition, because there is no such object of true cognition as an absence.

NS 2.2.8: [Answer] For [example], where several [cloths] are marked, since there are those unmarked which are marked [out] by the absence of marks, it is proved that this [viz. absence] is an object of valid cognition.

NS 2.2.9: If you say, "[There can be] no absence without the thing's [first] being present," [we say] no, because the mark can be [present] on something else.

NS 2.2.10: [Rejoinder of the Opponent.] But the fact that one finds those [viz., the marks on the marked cloths] is no reason for there being [an absence of those] on the unmarked cloths.

NS 2.2.11: [Answer] No, because [the absence of the marks is] proved by the presence of the marks [elsewhere].

NS 2.2.12: Also, because there can be an absence prior to a thing's coming into existence.

The basic argument in this exchange that Matilal brilliantly brings out is as follows.

The opponent informs us that there is not any unique sui generis kind of cognition of absence, since there are no absences to be cognized. No epistemology is required where there is no ontology to be engaged. The Nyāya respond with a behavioristic example. Imagine that one is told to go get the unmarked clothes from a stack of clothes that are both marked and unmarked. We can imagine that a person successfully does this, and as a consequence, we can conclude that cognition of the absences of marks is a condition for how the behavior was successfully executed. The opponent does not like this move, and responds by saying that the absence of marks is cognized by the fact that the person first has an understanding of marks, and notices that those are missing from certain cloths. The Nyāya respond that those marks are present elsewhere, on marked clothes, but not present on the unmarked clothes, since those cloths where never marked. 
The opponent disregards this, since there still were marks in the first place somewhere. This leads us to the interesting case where the opponent has no move, 2.2.12, what about a case of absence where entity is coming into existence for the first time.

There are two readings of this case: the token and the type. A token instance can be handled by a prior token of the same type. However, a new type cannot be handled in the same way. So, if there are absences of entities that are of a new type, and they can be perceived, we have an open pathway to an engaging argument for Farennikova's MMmodel and M\&D's MCM-model for explaining the phenomenology and cognition of absence.

1. MM and MCD can explain three kinds of absence: (i) failed searches, (ii) primedpattern, and (iii) disappearance.

2. The Nyāya accept the not-yet type of absence, and there are not-yet type of absences.

3. The not-yet type of absence cannot be reduced to either of (i)-(iii).

4. The not-yet type of absence cannot be explained by extension from (i)-(iii).

$\therefore$

5. Neither MM nor MCD can explain all the kinds of absences there are.

The key defense will come at (2)-(4). This is but one point we can arrive at from an engagement with the Nyāya. Many other points can be found in the Matilal's work.

J. L. Shaw (2016: 103) points us toward another fascinating point about perception in the Nyāya theory that should be interesting for further investigation. On the Nyāya account of perception there are both positive and negative causal conditions for the production of the perception of an absence. Negative causal conditions, are argued by them, to be non-reducible to positive causal conditions. We will forgo discussion of the positive conditions, since the interesting engagement will derives from the negative conditions. Keeping in mind that the Nyāya have an ontology that accepts both positive and negative entities, that is both presences and absences, the negative conditions are the following:

(i) An object, either positive or negative, should not be too far.

(ii) An object, either positive or negative, should not be too close.

(iii) An object, either positive or negative, should not be overshadowed by another object, screen, or obstruction.

(iv) An object, either positive or negative, should not be mixed up with things that it is too similar to.

Examples in the positive case can be used to help understand these negative causal conditions. In the case of (i) an object that is too far away, such as a post, might be thought to be a person because the distance impedes the proper causation of the perception. In the case of (ii), if an object is too close, then perhaps one cannot make out its specific color or boundaries. In the case of (iii) an object may not be salient in the right way because it is overshadowed by something else. For example, during the day the stars are not visible because the sun's rays overshadow them. And in (iv), when things 
are too similar they cannot be differentiated. For example, raindrops cannot be perceived separately in a river because they are too similar to the river.

What is important about these conditions is that they apply not only to perception of a present object, but also to the perception of the absence of an object. The conditions divide into two groups. The first group, consisting of (i) and (ii), have to do with enabling object perception. The second group, consisting of (iii) and (iv), have to do with object salience. The interesting negative conditions for consideration of absence are (iii) and (iv) not being overshadowed and not being too similar. Our core question is: how do these negative causal conditions pertain to Farennikova's MM model of the perceptual view of absence?

Finally, as we noted in our analytical commentary on the Farennikova and Martin \& Dokic, there is an interesting question in the philosophy of perception that arises by putting together research on the perception of absence and non-representational theories of perception. Again, the core question is: how does disjunctivism interact with realism about the perception of absence?

It is well known in the literature on Nyāya that they defended some kind of naïve realist picture of perception, and knowledge based on perception. Matilal's (1986) classic Perception: An Essay on Classical Indian Theories of Knowing is a great source for research on perception in general, but for those exploring disjunctivism and Indian philosophy, it is an important place to get a firm footing on the space of options concerning perception in Indian philosophy. There are two points that one should begin with when considering this question.

First, can the Nyāya theory of perception be properly characterized as a form of disjunctivism similar to the one advocated by John McDowell, the foremost proponents of disjunctivism. In the recent literature Dasti \& Phillips (2010) and Dasti (2012) have offered an engaging argument for the claim that some Nyāya philosopher's, such as Gangeśa appear to articulate / defend epistemic disjunctivism. Ganeri (2010) has offered a critique of this claim with respect to Gangeśa, based on the form of epistemic naturalism that Gangeśa advances. Vaidya (2013) has challenged the idea that the Nyāya defend epistemic disjunctivism. Instead, using Matilal's (1986) account of the Nyāya Misplacement Theory of Illusion, in his (2015), he articulates and argues for the view that the Nyāya have a novel view called causal-disjunctivism, which is distinct from epistemic disjunctivism.

Second, as Matilal (1968) is at pains to show and articulate, the Nyāya articulate and defend an ontology that accepts absences. And as we have shown here, they defend the view that the best explanation for our knowledge of absence is perception, as opposed to non-apprehension, which the Mīmāmsā defend. This sets up the view that, in some way, the Nyāya have engaged the question: how does disjunctivism engage realism about the perception of absence? We note, that in contrast to the Nyāya, John McDowell has not even engaged the question of disjunctivism and realism about absence. And that the debate on the perception of absence that is just beginning has not engaged how a nonrepresentational account of perception might go in for an explanation of the phenomenon.

As Shaw (2016), following off of work done by Matilal (1986), articulates is that the Nyāya theory of perception is an account of how positive and negative causal conditions allow for the perception of an object. And this theory of perception does not 
posit an image in the mind that is the chief site of perceptual action. This account, for them, can be extended to both the perception of presence and absence.

\section{Discussion of Absence in Bhāṭța-Mīmāmsāā}

In this section we will make a series of critical points deriving from the Bhātta-Mīmāmsā literature. Some of these points build off of comments we made in the Nyāya section. However, some of them depart, owing to the nature of this particular school of classical Indian philosophy.

First, as we noted in earlier Farennikova, as well as M\&D, focuses their discussion of the perception of absence on a certain set of cases. We will take note here of the paradigm case Farennikova investigates.

Our life is replete with more mundane examples. We discover that there is no milk in the fridge, notice an absence of a colleague in a meeting, or see that the keys are missing from the drawer. These are routine cases of perceiving an absence. (Farennikova 2013: 430)

These cases all come under the ontological heading of prior-presence-complete whole, or what she calls failed searches. We go looking for the milk, and don't find it, we notice an absent colleague who should be at a meeting, and we see the keys are missing because we searched for them in the drawer and didn't find them. In each case there is an object that we have experience before, are familiar with, and which in a given moment of investigation or noticing we come to have an absence experience. In the prior section we argued that one kind of absence discussed in the Nyāya, the not-yet kind of absence, is a problem for the MM model that Farennikova defends, and perhaps even the MCD-model of M\&D. Moving away from the points related to the Nyāya School of philosophy, we will move into a similar point deriving from the Bhātța-Mīmāṃsā School. We begin with a more exhaustive presentation of the different kinds of absence found in the BhâttaMīmāṃsā literature.

Bilimoria (2015: 199) offers a presentation of the different kinds of absences that a more complete account of the perception of absence must engage.

1. Prägabhāva: the 'not-yet so' type of absence, such as the absence of the existence of a table in its parts just prior to the completion of its construction.

2. Dhvamsābhāva: the 'no-more' type of absence, such as the absence of the existence of a table in its parts just upon the destruction of it.

3. Anyonyābhāva: the 'not-related' type of absence, such as the absence of a horse in a cow.

4. Atyantābhāva: the 'never-never' type of absence, such as the absence of a circlesquare.

With these absences in place we can easily generate some further questions for the theory of absence, based on the argument in the prior section. The focus now is on the "nevernever' type of absence. And the argument is virtually the same. It derives from the 
question: how can the MM-model explain the never-never type of absence? However, one might wonder: what reasons stand in favor of accepting these kinds of absences? Kurmāila offers several arguments at the ontological-epistemological nexus. Bilimoria (2015: 195) offers a rendering of the core ideas.

\section{Kumārila Bhaț̣a 1}

1. If we do not admit these four kinds of negation, antecedent, posterior, mutual, absolute, it would not be possible to differentiate between cause and effect.

2. There is a difference between cause and effect.

$\therefore$

3. We must admit the four kinds of negation.

\section{Kumārila Bhațta 2}

1. The nature of absence, as pointed to by negation, is either real or illusive.

2. If the nature of absence is illusive, than one must say that the effect exists prior in its cause. For example, the curd is non-existent in the milk from which it is produced. And since negation is illusive, and there is no absent entity that is real, the curd must exist prior in its cause.

3. The effect does not exist prior to its cause. For example, the curd does not exist in the milk prior to its production. So, the curd is absent in the milk prior to its production.

$\therefore$

4. The nature of absence is real.

\section{Kumārila Bhaț̣a 3}

1. A cow is decisively absent from a horse, and a horse is decisively absent from a cow.

2. Decisive absence can only be understood through the idea of "a thing's being positive from their own standpoint, and negative from that of another.

$\therefore$

3. Absences are real.

\section{Kumārila Bhaț̣a 4}

1. If the absolute absence of (color in the air) were not in the air, (fire) in water, or (horns) in a hare, we would be forced to say otherwise, since we could not understand 'it is not the case that color is in the air' as something partial.

2. We are not forced to say otherwise.

$\therefore$

3. So, the absolute absence suggests a real entity that is absolutely absent. 
Kumarila Bhatța offers the following insight.

A judgment (nirnaya), concerning a (positive) existent (bhāva)-such as 'this is (the jar) and nothing else' - is not possible without reference to the cognition of absence of everything else. Nor is the knowledge (samvrtti) that 'it (the jar) does not exist' possible, without reference to the negated thing itself; for there can be no cognition without and objective substratum. (Bhatta 1985, \#15-16)

Bilimoria (2015) offers the following account of the significance its significance.

What Kumārila seems to be suggesting in this passage, which is brought out more clearly in a later passage, is that the function of perception is over once our sense-organ fails to make contact with an objective substratum out there (arthasyendriyasannikrsț asyabädbha) and there thus is non-generation of perception, inference, and so on. Instead, there is a stark absence of that object (nastitya-syarthasya); now this 'absence' is presented phenomenologically or noetically in the mental grasping, as he comments: "After the object (the place where the jar is not present) has been perceived, and the counter-entity (the jar) has been remembered, then follows the notion that it (the jar) is not, which is purely mental (and as such) independent of the sense-organ" (Bhatța 1985, \#27).

So, the judgment ' $p$ ' implies denial of 'not- $p$ '; hence, all meaningful positive judgments embed negative cognitive essence -they are not mutually contradictory as Śankara later wanted to argue. When the judgment tilts to the latter, in full view, literally, of the absence of ' $p$ ', we say in respect of the negative cognitive entity, 'not- $p$ '. There cannot be a cognition without reference to some object or other. Kumārila is being consistently realist, perhaps a naïve negative realist! (Bilimoria 2015: 197)

Second, the core view in the Bhātța-Mīmāṃsā school is that the cognition of absence is to derive from non-apprehension (anupalabadhi), where non-apprehension is not the same as inference (anumāna). This leads to a very interesting question, which we signaled early on: Do either, or even both, MM and MCD fit in the interesting option offered by non-apprehension. Can the phenomenology of absence and the cognition of absence be correctly characterized as a kind of non-apprehension at one level, which can then be argued to be instantiated by either the perceptual view or the metacognitive view? In addition, one might ask: does the non-apprehension view offer a distinct alternative that can be explored in cognitive science and vision science? We think these questions offer a novel opportunity for future discussions of the epistemology of absence. We conceive this project to be somewhat similar to the idea that Evan Thompson (2015) articulates in his "Dreamless Sleep, the Embodied Mind, and Consciousness: the Relevance of a Classical Indian Debate to Cognitive Science.” He proposes 
The philosophical schools of Advaita Vedānta and Yoga maintained that consciousness is present in dreamless sleep, whereas the Nyāya School maintained that it is absent. Consideration of this debate, especially the reasoning used by Advaita Vedānta to rebut the Nyāya view, calls into question the standard neuroscientific way of operationally defining consciousness as "that which is appears in dreamless sleep and reappears when we wake up or dream." The Indian debate also offers new resources for contemporary philosophy of mind. At the same time, findings from cognitive neuroscience have important implications for Indian debates about cognition during sleep, as well as for Indian and Western philosophical discussions of the self and its relationship to the body. Finally, considerations about sleep drawn from the Indian materials suggest that we need a more refined taxonomy of sleep states than that which sleep science currently employs, and that contemplative methods of mind training are relevant for advancing the neurophenomenology of sleep and consciousness. (Thompson 2015:1, emphasis added)

Likewise, we think that the Nyāya-Bhātța Mīmāṃsā debate on the epistemology of absence can yield new and interesting ideas. In particular, we think that vision science and Mīmāmsāa scholarship could lead to an interesting engagement on the topic of absence. There are two important avenues of exploration. What does the extant literature on absence (abhāva) and non-apprehension (anupalabadhi) reveal as options for a more robust understanding of the view? The other avenue requires looking further into cognitive science and vision science.

\section{Conclusions and Future Directions}

Contemporary western philosophers often look at classical Indian philosophy and discussions of it in the $20^{\text {th }}$ century as a tradition of mere commentary. That is, new insights, conversations, and philosophies don't emerge from these traditions; all that happens is that scholars comment on ancient texts and each other's work. While this is not an incorrect characterization of a lot of work that is done under the banner of "Indian philosophy", it would be a mistake to say that work like this is not important for further discussion in global philosophy. More importantly, though, this is a mischaracterization of a lot of what has come out of $20^{\text {th }}$ century classical Indian philosophy, especially in the work of Matilal, and several of those that worked with him and were inspired by him (among them two authors of this paper). He clearly showed in his (1968) and (1986) how much classical Indian philosophy has to offer the best of progressive work in analytic philosophy. And those working under him have carried his work forward. We would like to highlight the continued discussions that go beyond mere commentary and into the area of discussing new examples and how to extend a theory forward into new terrain. Recall, the objection, discussed by Farennikova and M\&D, deriving from cases of non-surprise absence. These cases are problematic for all of those involved in the debate. For example, if, as M\&D, claim all instances of absence experience are cases involving the feeling of surprise, then what happens in cases where there is no feeling of surprise? Not long ago a 
related exchange between a contemporary Nyāya scholar, Jaysankar, and a BhātțaMīmāṃsā scholar, Purushottama, occurred. Consider the following dialogue exchange:

A Key Exchange for the Nyāya-Bhātța-Mìmāmsāa Debate:

Jaysankar: The Nyāya pushes the idea that one must cognize the relevant object searched for prior to the cognition of absence due to failure of the search.

Purushottama: Consider the following example, the Key Case. I go searching for my wallet in my drawer. I have cognized my wallet prior to the search in my drawer. I don't find the wallet. I have cognition of the absence of my wallet. But, I also have cognition of the absence of my keys in the drawer, which I did not go searching for. So, the pattern of the problem is that I have cognition of the absence of my keys, which was not due to a prior cognition of my keys being present in my mind. That is, I didn't search for my keys, yet I came to know the absence of my keys.

Jaysankar: That is not a problem. The Nyāya would analyze the Key Case in the following way. First, they would posit the existence of a disposition for the cognition of the key, because you usually keep your keys in your drawer, and you have the concept of keys. Second, when you go searching for your wallet the disposition for the key is activated. As a consequence, when you go searching for the wallet, you first cognize the absence of the wallet, and then the disposition for the key kicks in and you also cognize the absence of the key. So, the core idea in Nyāya is to allow for a distinction between the primary cognition of absence due to what is searched for vs. those cognitions of absence that occur because of activated dispositions.

Purushottama: This is a very interesting extension of the Nyāya view. However, it is problematic because it seems as if I should then have a number of absences cognized when I go searching for my wallet. Not only are my keys absent so is my lucky stone, which I also keep in the drawer. However, I only got the cognition of the absence of the keys, but not the lucky stone. Yet both dispositions were activated by the mere fact that I went searching for my wallet.

Jaysankar: Outstanding example. The Nyāya would appeal to regularity in association, rather than mere association. It is likely the case that you keep your keys in the drawer more frequently than you keep your stone in the drawer with the wallet. Because of the difference between the regularity only the key disposition gets activated.

Purushottama: Differences in regularity will not suffice. Because I can easily change the example so that we have a case where the wallet, the keys, and the luck stone are always kept together all the time. In that case there is no 
difference in regularity. And it is surely the case that I can cognize the absence of the wallet due the search for it, followed by cognition of the absence of the keys not due to the search for it, and never cognize the absence of the lucky stone.

Jaysankar: Yes this is a difficult case. Perhaps there is some significance that one object, the key, as opposed to the lucky stone, has that plays some an important role.

Purushottama: Yes, I think that is correct. But then it seems as if cognition of absence is not due to perception of absence in light of a prior thought about the object. Perhaps the causal conditions that go into the perception of absence require a plethora of causes. Cognition of absence is a deep debate and though we have traced some of the ground here I think we need to pay heed to the fact that these issues cannot be quickly decided. The classical Indian philosophers that have come before us have spent years debating these issues.

Jaysankar: I agree! We have not even discussed the contributions from the Buddhists and other schools.

It is clear that the exchange takes into consideration an interesting case that must be considered by the perceptual view. And it shows that contemporary scholars of Indian philosophy, using the resources of classical Indian philosophy, can move forward theories by their nuanced understanding of the texts and the traditions. This is at least of the brilliant aspects of Matilal's work that we find fascinating.

Finally, our estimation of the work done by Farennikova, Martin \& Dokic is that it is highly engaging and valuable, and that it marks an important advance in thinking about absence in the human condition. However, our hope is that future discussions of metaphysics, epistemology, ethics, political philosophy, and all that can fall under 'philosophy' as a global enterprise, embrace the spirit of Matilal's method of doing philosophy - a method, as some recent philosophers have pointed out - that involves dropping the fence by which we keep and patrol intellectual borders. Thinkers in every tradition are important for investigation of a phenomenon experienced by all. Inquiry in ontology, epistemology, and ethics is not the privilege of specific cultures. It is open to all, for it is what allows them to create a way of being -through an understanding of what is, how one can know, and thus how one should be.

\section{References}

\section{Primary}

Bhaț̣a, Kumārila. Ślokavārtika. Translated by Ganganatha Jha. Asiatic Society of Bengal, Calcutta 1985. 
Bhaț̣a, Nārāyaṇa [of the Bhātța School]. Mānameyodaya. Translated by Śrīdīnanātha Tripathī, Sanskrit College, Calcutta, 1989.

Viśvanātha, Bhāṣā-paricheda, with Siddhānta-muktāvalī. Ed. Jīvānanda Vidyāsāgar Bhaț̣āchārya. Bibliotheca Indica, Calcutta 1883; translated by Swami Madhvananda. Advaita Ashram, Calcutta, 1977.

\section{Secondary}

Bilimoria, P. 2015. Negation (abhāva), Non-existents, and a Distinctive pramāna in the Nyāya-Mīmāmssā. In P. Bilimoria and M. Hemmingsen (eds.) Comparative Philosophy and J. L. Shaw. Sophia Studies in Cross-cultural Philosophy of Traditions and Cultures, Springer International Publishing. Dordrecht/NY: 183202: 183-140.

Dasti, Matthew. 2012. "Parasitism and Disjunctivism in Nyāya Epistemology" Philosophy East and West 62.1: 1-15.

Dasti. M, \& Phillips, S. 2010. Pramāṇa Are Factive-A Response to Jonardon Ganeri. Philosophy East \& West 60.4: 535-540.

Farennikova, A. 2013. Seeing Absence. Philosophical Studies 166: 429-454.

Ganeri, J. 2007. Review of Epistemology of Perception: Gañgeśa's Tattvacintāmaṇi, Jewel of Reflection on The Truth (about Epistemology): The Perception Chapter (pratyakșa-khanda), by Stephen Phillips and N. S. Ramanuja Tatacharya. Journal of the American Oriental Society 127 (3): 349-354.

Ganeri, J. 2010. A Study of Indian Epistemology: Questions of Method --A Reply to Matthew Dasti and Stephen H. Phillips. Philosophy East \& West 60.4: 541-550.

Guha, N. 2013. No Black Scorpion is Falling: An Onto-Epistemic Analysis of Absence. Journal of Indian Philosophy 41(2): 111-131.

Koriat, A. 2000. The Feeling of Knowing: Some Metatheoretical Implications for Consciousness and Control. Consciousness and Cognition 9 :149-171.

Koriat, A. 2007. Metacognition and Consciousness. In P. D. Zelazo, M. Moscovitch, and E. Thompson (eds.) Cambridge Handbook of Consciousness. Cambridge University Press: 289-326.

Matilal. B. K. 1968. The Navya-Nyāya Doctrine of Negation: The Semantics and Ontology of Negative Statements in Navya-Nyāya Philosophy. Harvard Oriental Studies Series 46. 
Matilal. B. K. 1986. Perception: An Essay on Classical Indian Theories of Knowledge. Oxford University Press.

Martin, J \& Dokic, J. 2013. Seeing Absence of Absence of Seeing. Thought Vol. 2.2: 1-9

McDowell, John. (2009). "Criteria, Defeasibility, and Knowledge” in Byrne, A. \& Logue, H. (Eds.) Disjunctivism: Contemporary Readings. Cambridge, MA; MIT Press: $75-91$.

Shaw, J. L. 2016. Nyāya on the Sources of Knowledge. In J. L. Shaw (eds.) The Collected Writings of Jaysankar Lal Shaw: Indian Analytic and Anglophone Philosophy. Bloomsbury Publishing: 100-173

Vaidya, A. 2013. Nyāya Perceptual Theory: Disjunctivism or Anti-Individualism? Philosophy East \& West 63.4: 562-585.

Vaidya, A. 2015. The Nyāya Misplacement Theory of Illusion \& the Metaphysical Problem of Perception. In P. Bilimoria and M. Hemmingsen's (eds.) Comparative Philosophy and J. L. Shaw. Springer Publishing: Dordrecht / NY: 123-140

Thompson, E. (2015), "Dreamless Sleep, the Embodied Mind, and Consciousness: the Relevance of a Classical Indian Debate to Cognitive Science," $<$ http://openmind.net/papers/dreamless-sleep-the-embodied-mind-andconsciousness-therelevance-of-a-classical-indian-debate-to-cognitive-science>. 


\author{
Purushottama Bilimoria \\ Senior Lecturer and Visiting Scholar respectively \\ Graduate Theological Union and UC Berkeley, CA \\ Dharma/Hindu Studies \\ 2400 Ridge Road \\ Berkeley CA 94709 \\ Tel 6313351366; 510-649-2580 \\ pb1@unimelb.edu.au
}

